\title{
Future Primary School Teachers Attitudes toward Intercultural and Bilingual Education in Primary Schools
}

\author{
Vlasta Hus, Polona Jančič Hegediš \\ Faculty of Education, University of Maribor, Maribor, Slovenia \\ Email: vlasta.hus@um.si,polona.jancic1@um.si
}

How to cite this paper: Hus, V., \& Hegediš, P. J. (2018). Future Primary School Teachers Attitudes toward Intercultural and Bilingual Education in Primary Schools. Creative Education, 9, 2939-2949. https://doi.org/10.4236/ce.2018.916221

Received: November 26, 2018 Accepted: December 25, 2018

Published: December 28, 2018

Copyright $(0) 2018$ by authors and Scientific Research Publishing Inc. This work is licensed under the Creative Commons Attribution International License (CC BY 4.0).

http://creativecommons.org/licenses/by/4.0/

\begin{abstract}
This article analyses the attitudes of future primary school teachers, who, are currently students of the elementary education programme, toward intercultural and bilingual education. The problem is examined from three different aspects, the opinion of the students concerning the applicability of intercultural and bilingual education, advantages and disadvantages of intercultural and bilingual education and, lastly the knowledge of intercultural and bilingual education in bilingual primary schools. Interculturalism is a current topic in society today and can be presented as an ethnic-political project that aims at solving problems of co-existing in multi-ethnic societies. Intercultural education is therefore an opportunity and a reason to change educational approaches. A key element for providing lessons that include elements of intercultural education is bilingual education as well as a highly qualified primary school teacher. The research shows that the future primary school teachers believe to have good knowledge of intercultural and bilingual education and believe this way of educating to be the most appropriate and useful for the children of minorities to learn a foreign language. The participating future teachers stated students' ability to speak more languages and gaining multiand intercultural experiences as the advantages of intercultural and bilingual education. Half of participating future teachers do not recognize any disadvantages of intercultural and bilingual education, while others recognize additional teachers' obligations and possible specific students' learning problems as a potential disadvantage.
\end{abstract}

\section{Keywords}

Education, Primary School, Students, Intercultural, Bilingual 


\section{Introduction}

Multiculturalism is understood as the co-existence of several different cultures in one space, mixing of cultures in the society and, on an individual basis, as openness to other and foreign cultures (Konečnik Kotnik \& Javornik, 2011). In principle, multiculturalism is an ideology protecting and promoting the variety of cultures (Rizman, 1998). On the other hand, talking about interculturalism is talking about an ethnic-political project that aims at solving problems of co-existing in multi-ethnic societies with promoting active meetings and continuous communication between them. Interculturalism means understanding and mutual exchanges resulting in cultural enrichment of both individuals and groups in society in general (Marazzi, 1998). Interculturalism is based on dynamic cultural concept that is sensitive to changes and is constantly being transformed. Various intercultural activities are primarily planned for the educational use. The aim of intercultural education should not only be discovering the differences and interacting with people of different origin, social class, gender, religion, sexual orientation etc., but it should evaluate and work on the similarities that connect people. Intercultural education should therefore be an established process representing the basic culture of the future that is continually renewed in and through everyday practice. Interculturalism can also be defined as a perspective, way of confrontation and dialog between different people, which is not a spontaneous act, but has to be worked upon. In this way we fight against passivity, stereotypes, prejudices, indifference and hostility, whether it is hidden or open, thereby all cultural differences, conflicts, old and new forms of racism, development models and their effects become part of curriculum content. Interculturalism therefore does not teach new sciences and does not introduce measures for preventing school failure of emigrant children nor it is limited to the organization of special events celebrating peace, co-existence, solidarity (Vrečer, 2009). Intercultural education therefore enables continuous deconstruction and reconstruction of educational approaches (Sirna Terranova, 1997; Zoletto, 2007). It is a radical change of education system, changing it from the system of reproduction of existing and repetitive organizational and cultural patterns to the place of cultural mediation, consequently adding new contents to the curriculum (Vrečer, 2009).

A key element for providing lessons that include elements of intercultural education is bilingual education. The term bilingual education does not have a standard definition and can have different meanings in terms of organization, content, and objective, since every educational model is the result of social and political indicators (Novak Lukanovič \& Zver, 2013). In Slovenia the bilingual education system, sometimes defined as the two-way model, was introduced to protect the future of minorities. Bilingual schools in the nationally mixed areas include students of usually two nationalities, which gives them opportunities to learn both languages and the historical and cultural achievements of both nations, since various contents related to the history and the culture of the other 
nation are added to the classes (Varga et al., 2005; Nećak Lük, 2013). Bilingual education in Slovenia reflects the respect for others and signifies equality for ethnic groups. It is a cultural and linguistic knowledge of either majority or minority (Hus \& Jančič, 2018). New guidelines for bilingual education were developed after the reform of the Slovenian school system in the 1990's and the introduction of nine-year primary education and now in bilingual schools both languages are taught as subjects at all levels (Nećak Lük, 2010, 2013).

Sixty years ago, it was thought that bilingualism led to cognitive weakening, however experts later dismissed the thesis and proved that bilingual speakers achieved better results in tasks demanding problem solving and creativity and were able to think in a more flexible way. Bilingualism is thought to have positive effect on child's verbal, cognitive and personal development as well as on their school success (Pertot, 2011). Bilingualism is confirmed to be child's advantage rather than disadvantage. It has positive effect on a child's general cognitive development, as it encourages divergent way of thinking, increases capacity of linguistic analysis, affects children's meta-linguistic awareness, encourages social-cognitive development and positive understanding of themselves and the language (Marjanovič Umek, Kranjc, \& Fekonja, 2006). One of the possible disadvantages of bilingual education is children's code-mixing. Some children never or rarely mix languages. Children who experience code-mixing first mix individual words and can later mix grammar rules as well. Code-mixing is often proved to be a consequence of poor vocabulary knowledge and should therefore not be a sign of confusion and child's inability to differentiate languages. The second disadvantage we are going to mention is semilingualism or partlingualism which is the opposite of bilingualism. It refers to the speaker's underdeveloped language ability in two or more codes or languages. It has a great effect on child's personality due to learning and emotional difficulties. Semilingualism should not be viewed as a personal deficit, but as a phenomenon that is typical for minorities exploring and questioning their identity (Pertot, 2011).

Bence (2011), Bernjak (2004, 2009), Kolláth (2005, 2009), Nečak Lük, (2011) and Novak-Lukanovič (2009) have been trying to analyse the basic parameters, efficiency and results of bilingual education. To achieve this, they attempt to exceed the local and regional frames, as well as put the studies into the concept of the European Union. Hus and Jančič (2018) present their research with the results, noting that there can be found enough literature discussing the models of bilingual education. At the same time, they are noting that there is a deficit of qualitative research and analyses conducted to provide an evaluation of the bilingual model of education on different levels, since bilingual model of education is a complex concept deserving of future exploration.

\section{Methodology}

\subsection{Purpose of the Study}

The purpose of the study was to examine the future primary school teachers and 
their attitudes toward multicultural and bilingual education. To be more concrete, we focused on the attitudes and the opinions of the future primary school teachers toward the bilingual education for minorities in Carinthia on the basis of convenience sample. Beside schools with German as the language of instruction, there are so-called bilingual schools where both, German and Slovene language, are language of instruction. This Austrian regional educational offer is intended for Slovenian national community in Carinthia. Slovenians in Austria represent indigenous national minority living in the south of Carinthia on the territory of $2537 \mathrm{~km}^{2}$ and in the south of Styria on the territory of $85 \mathrm{~km}^{2}$. It is a remainder of a relatively larger Slovenian ethnic land lost by shrinking during the Germanization in the $19^{\text {th }}$ and $20^{\text {th }}$ century. The majority of Corinthian Slovenians live in the Klagenfurt Basin. In the beginning of the $19^{\text {th }}$ century the Klagenfurt Basin was entirely Slovene land, with the exception of the narrow northern part, whereas today they are only present in the southern part of the Basin. Language identity is one of the most sensitive issues in Carinthia, as it is largely associated with the ethnicity. Language, whether it is German or Slovene, defines one's nationality either intentionally or unintentionally. Slovenian language represents the language of domestic purposes-associated with intimate family circle, relatives and friends-and is therefore exclusive and typically unwelcome in public. On the other hand, German language is the language of public use (Zavratnik Zimic et al., 1998). The trend of enrolment in bilingual schools in Carinthia has been increasing in the past years or has been the same.

The opinions of future primary school teachers were examined concerning the applicability of bilingual education, the advantages and disadvantages of bilingual education as well as the knowledge of intercultural and bilingual education in bilingual schools.

\subsection{The Basic Research Study}

The study was based on a descriptive and non-experimental method of empirical research. The researchers did not implement any form of pedagogical experiment during this first phase of research, thus the most appropriate research method was descriptive statistical method of empirical research. It is typical for the descriptive research method of empirical pedagogical research to teach by describing facts, relationships and processes without sample explanation. The answers to the research questions were collected by using an extensive approach, i.e. using the questionnaire.

\subsection{Sample}

The number of students, future primary school teachers, selected for the convenience sample, was 48 . The sample is not representative since we included only one residential area of Slovene National Minority, but yet still gives us valid basic insight. The research sample is comprised of 33.3\% male students (16) and $66.7 \%$ female students (32). In regard to student age, the research sample consisted of $72.9 \%$ of students ranging in age from 20 to 25 and $27.1 \%$ of students 
ranging in age from 26 to 30 .

\subsection{Data Collection}

Data for all variables were collected using online questionnaire. The questionnaire was prepared for the students, enrolled in the faculty programme for primary school teachers. Questionnaire for collecting data had verified metric characteristics (validity, reliability, and objectivity). Validity was ensured by reviewing and pre-testing the questionnaire on a sample. Reliability was controlled from the start of creating questions, and the researchers were careful to provide detailed instructions and unambiguous specific questions. Objectivity was controlled with the selection of closed questions, which cannot be changed with the subjective assessments of information. Objectivity of the instrument was based on individual online interviewing without the presence of assessor. The questionnaire consisted of various types of questions: dichotomous and closed-ended. The data were acquired and analysed in the school year 2017-2018. The questionnaire for students prepared in an online form and sent to e-mail addresses of students. 48 fully completed questionnaires were received.

\subsection{Data Analysis}

The data obtained from the questionnaire were analysed using the SPSS statistics programme Data was processed using basic descriptive statistics, frequency distribution.

\section{Results}

Results are presented in three thematic content blocks: 1) The applicability of bilingual education, 2) Advantages and disadvantages of intercultural and bilingual education and 3) Knowledge of intercultural and bilingual education in bilingual schools.

\subsection{The Applicability of Bilingual Education}

Table 1 shows that $54 \%$ of participating future primary education student teachers responded that intercultural and bilingual education is the best strategy to learn foreign language. $27 \%$ of participants replied that intercultural and

Table 1. Number (f) and structural percentage (f\%) of students' opinions whether intercultural and bilingual education is useful strategy to learn foreign language.

\begin{tabular}{ccc}
\hline Answers & f & f\% \\
\hline Best strategy to learn foreign language & 26 & 54 \\
Useful strategy to learn foreign language & 13 & 27 \\
Partially useful strategy to learn foreign language & 9 & 19 \\
Not useful strategy to learn foreign language & 0 & 100 \\
Total & 48 & \multirow{2}{*}{0}
\end{tabular}


bilingual education is useful strategy to learn foreign language while $19 \%$ of participants replied that intercultural and bilingual education is a partially useful strategy to learn foreign language. None of the participating student teachers responded that intercultural and bilingual education is not useful strategy to learn foreign language.

Participants-future primary school teachers were further asked to express their opinion whether intercultural and bilingual education is the best possible education for Slovene/Austrian primary school student to learn foreign language and results are presented in Table 2.

83.3\% of participating student teachers replied that it was their opinion that intercultural and bilingual education is the best possible education for Slovene/Austrian primary school student to learn foreign language, while $16.7 \%$ did not agree and replied that it is not the best possible education for Slovene/Austrian primary school student to learn foreign language.

\subsection{Advantages and Disadvantages of Intercultural and Bilingual Education}

Table 3 presents the opinions concerning the advantages of intercultural and bilingual education of future primary school teachers.

It can be concluded from Table 3 that a majority of student teachers recognise the ability to speak more than one native language as the greatest advantage of intercultural and bilingual education. In this question was possible to choose more than one answer. As another important advantage, 22.6\% of participants recognized gaining multi and interculturalism experiences and $18.9 \%$ of participants also recognized diversity of learning content in their lessons. Acquisition

Table 2. Number (f) and structural percentage (f\%) of students' opinions whether intercultural and bilingual education is the best possible education for Slovene/Austrian primary school student to learn foreign language.

\begin{tabular}{ccc}
\hline Answers & f & f\% \\
\hline YES & 40 & 83.3 \\
NO & 8 & 16.7 \\
Total & 48 & 100.0 \\
\hline
\end{tabular}

Table 3. Number (f) and structural percentage (f\%) of students' opinions about advantages of intercultural and bilingual education.

\begin{tabular}{ccc}
\hline Advantages & $\mathbf{f}$ & $\mathbf{f} \%$ \\
\hline Ability to speak more languages & 23 & 43.4 \\
Multi and intercultural experiences & 12 & 22.6 \\
Acquisition of lifelong learning & 5 & 9.4 \\
Diversity of learning content & 10 & 18.9 \\
Acquisition of additional teachers' professional competencies & 3 & 5.7 \\
Total & 53 & 100.0
\end{tabular}


of additional teachers' professional competencies was recognised as an advantage only by $5.7 \%$ of participating student teachers. The second portion of this question is recognising disadvantages of intercultural and bilingual education, with the presented in Table 4.

In addition to the recognized advantages in Table 3, we can conclude from Table 4, based on the fact that $52.1 \%$ of participating students replied that there are no disadvantages of intercultural and bilingual education. $20.8 \%$ of participating student teachers exposed additional teachers' obligations as a disadvantage. Another recognized disadvantage by $14.6 \%$ of participants are specific students learning problems that can occur during multicultural and bilingual education. Some other disadvantages that were not ranked as important as others discussed above are: additional students input in lessons, loss of identity and additional work in language customization.

Considering advantages and disadvantage we asked future primary school teachers whether in their opinion, it is reasonable to continue with intercultural and bilingual education in higher classes of primary schools, meaning also after students are fluent in the other language. $91.7 \%$ of participating future primary school teachers replied that is would be advisable to continue with the intercultural and bilingual education in order to maintain languages autochthonous. Only 4 participants (8.3\%) believe that intercultural and bilingual education should be ended after students are fluent in another language.

\subsection{Knowledge of Intercultural and Bilingual Education in Bilingual Schools}

Another important question was whether future primary school teachers believe that they are familiar with intercultural and bilingual education and where from do they have information about it.

Figure 1 demonstrates that the majority of participants believe that they possess enough knowledge and information about multicultural and bilingual education that they can say that they are familiar with the area of study. Student teachers were asked what their resources were to gain information and knowledge about intercultural and bilingual education, to which a majority of them

Table 4. Number (f) and structural percentage (f\%) of students' opinions about disadvantages of intercultural and bilingual education.

\begin{tabular}{ccc}
\hline Disadvantages & $\mathbf{f}$ & $\mathbf{f} \%$ \\
\hline Additional teachers' obligations & 10 & 20.8 \\
Specific students learning problems & 7 & 14.6 \\
Additional student input in lessons & 4 & 8.3 \\
Loss of identity & 1 & 2.1 \\
Additional work in language customization & 1 & 2.1 \\
There are no disadvantages & 25 & 52.1 \\
Total & 48 & 100.0
\end{tabular}




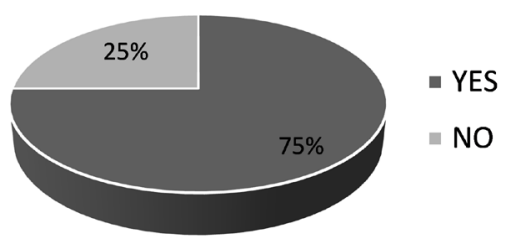

Figure 1. Number (f) and structural percentage (f\%) of students believes that they are familiar with intercultural and bilingual education.

responded that they gain information through media and internet (68.6\%) and from their teachers and professors at faculties (60.4\%). Some read books, scientific and professional articles (22.9\%). There were also $29.2 \%$ of participants who gained information and knowledge from their parents, friends and colleagues and faculty.

\section{Discussion}

This article examined the attitudes of the future primary school teachers, at this time still students of the study programme elementary education, toward intercultural and bilingual education. The research problem was approached from three different aspects-students' opinion on the applicability of intercultural and bilingual education, advantages and disadvantages of intercultural and bilingual education and, lastly, the knowledge of intercultural and bilingual education in bilingual primary schools. The results of the research show that the future primary school teachers believe to have good knowledge of intercultural and bilingual education, however it must be taken into consideration that this was their self-evaluation. For a more precise analyse one would need a qualitative empirical research with criteria or scales that could determine if the participating students really know intercultural and bilingual education which extends our study into further research. Intercultural education provides an opportunity and genuine reason to change the current generally accepted educational approaches. A key element for providing lessons that include elements of intercultural education is bilingual education. The results of this research show that the future primary school teachers believe this way of educating is the most appropriate for the children of minorities to learn a foreign language. As one of the advantages of intercultural and bilingual education they list students' ability to speak more languages. In bilingual primary schools separate and parallel methodology of language classroom organization can occur. Education, especially classrooms, are one of the most important areas where two languages can systematically meet. In the case of intercultural and bilingual education, this means that they serve as languages of instruction and, at the same time, both are students' first language in the mixed classrooms (Nećak Lük, 2013; Novak-Lukanovič \& Zver, 2013).

The second highest listed advantage of intercultural and bilingual education in the opinion of the participating students are multicultural and intercultural experiences that are consciously or unconsciously gained by students and also 
teachers in the process. According to Marazzi (1998), interculturalism means understanding and mutual exchanges resulting in cultural enrichment of both individual groups and society in general. Considering the current social environment, it would be reasonable for the intercultural education to become an established process, representing the basic culture of the future in the field of education and everyday life. By making cultural differences, conflicts, old and new forms of racism, development models and their effects a part of curriculum content, we fight against passivity, stereotypes, prejudices, indifference and hostility, whether it is hidden or open. From the results of question about disadvantages of intercultural and bilingual education it can be summed up that half of participating future primary school teachers do not recognize any disadvantages, while others in small percentage recognize additional teachers' obligations and possible specific students' learning problems as a disadvantage od intercultural and bilingual education. Researchers mention semilingualism as one of possible disadvantages regarding specific students' learning problems. The results of this question can lead one to doubt students' ability to predict the disadvantages intercultural and bilingual education can bring. It is therefore suggested that additional professional training take place in the form of training modules for students and new teachers, who would like or have already started to teach in a bilingual primary school. Those trainings, supported by professionals from faculties, could help them avoid potential negative consequences of bilingual education or at least help predict them and take appropriate measures.

Furthermore, the results show that in participants' opinion majority of them believe that they have enough knowledge and information about intercultural and bilingual education that they can say that they are familiar with. A highly qualified primary school teacher is the key element for providing bilingual education. The researchers, dealing with the role and the meaning of a teacher in bilingual education, also stated in their results that teachers play an important role in a successful bilingual educational process (Bokor, 2009; Kolláth, 2005, 2009; Nećak-Lük, 2011).

\section{Conclusion}

In conclusion, intercultural and bilingual education is an important part of the primary school educational system in minority areas of different countries in the European Union. Intercultural and bilingual education usually reflects the respect for others and signifies equality for ethnic groups and was designed to improve the level of education. It is important for the future primary school teachers to be aware of the importance of intercultural and bilingual education in the areas of national minorities and to know that its main aim is to provide a quality educational process and to give all students equal opportunities to continue their education. Our research can be valued addition in planning broader research. It can also upgrade curriculums for primary school future teachers by including additional intercultural bilingual contents in their educational programme. 


\section{Conflicts of Interest}

The authors declare no conflicts of interest regarding the publication of this paper.

\section{References}

Bence, L. (2011). A kétnyelvü oktatás története. In M. Király (Ed.), 50 éves a kétnyelvü oktatás a Muravidéken [50 Years of Bilingual Education in the Murmansk Region] (pp. 13-51). Lendava, Slovenia: Magyar Nemzetiségi Tájékoztatási Intézet.

Bernjak, E. (2004). A kisebbségi nyelvek jövője az EU-ban: Nyelvcsere vagy nyelvi revitalizáció [The Future of Minority Languages in the EU: Language Change or Linguistic Revival]. Kisebbségkutatás: Szemle a hazai és külföldi irodalomból [Minority Research: A Review of Domestic and Foreign Literature], 13, 221-228.

Bernjak, E. (2009). Medkulturna paradigma slovenistike v medkulturnem okolju. In M. Stabej (Ed.), Infrastruktura slovenščine in slovenistike. Simpozij 28 [Symposium 28] (pp. 57-63). Ljubljana: Znanstvena založba Filozofske fakultete.

Bokor, J. (2009). Nyelviség és magyarság a Muravidéken [Language and Hungarians in the Muravidék]. Lendava, Slovenia: Magyar Nemzetiségi Müvelődési Intézet.

Hus, V., \& Jančič, P. (2018). Slovenian Example of Bilingual Primary Education. Creative Education, 9, 1-10. https://doi.org/10.4236/ce.2018.91001

Kolláth, A. (2005). Magyarul a Muravidéken [In the Mura Region]. Maribor, Slovenia: Slavistično društvo Zora 39.

Kolláth, A. (2009). Két nyelv és oktatás. In A. Kollath (Ed.), A muravidéki kétnyelvü oktatás fél évszázada [Half a Century of Bilingual Education in Muravidék] (pp. 36-59). Bielsko-Biała, Budapest, Kansas, Maribor, Praha: Zora 68.

Konečnik Kotnik, E., \& Javornik Krečič, M. (2011). Spodbujanje multikulturnosti pri učencih [Promoting Multiculturality among Pupils]. Geografija v šoli [Geography at school], 20, 12-19.

Marazzi, A. (1998). Lo sguardo antropologico: Processi educativi e multiculturalismo [The Anthropological Gaze: Educational Processes and Multiculturalism]. Roma: Carocci.

Marjanovič Umek, L., Kranjc, S., \& Fekonja, U. (2006). Otroški govor: Razvoj in učenje [Children's Speech: Development and Learning]. Domžale: Izolit.

Nećak Lük, A. (2010). Iz preteklosti za prihodnost: pol stoletja dvojezičnega šolstva v Prekmurju. In J. Herman, T. Sabo, M. Pisnjak, \& E. Kiraly Patyi (Eds.), Drug z drugim: $O b$ 50-letnici dvojezičnega šolstva na narodnostno mešanem območju v Prekmurju [With Each Other: On the Occasion of the 50th Anniversary of Bilingual Education in the Ethnically Mixed Area in Prekmurje] (pp. 15-27). Lendava, Slovenia: Dvojezični vzgojno-izobraževalni zavodi na narodnostno mešanem območju v Prekmurju.

Nećak Lük, A. (2011). Tény, hogy a magyar nyelvet elsősorban a kisebbségnek kell használnia. In M. Király (Ed.), 50 éves a kétnyelvü oktatás a Muravidéken [50 Years of Bilingual Education in the Murmansk Region] (pp. 120-125). Lendava, Slovenia: Magyar Nemzetiségi Tájékoztatási Intézet.

Nećak Lük, A. (2013). Metodologija jezikovne organizacije dvojezičnega pouka. In M. Pisnjak, M. Berden, \& J. Novak Csaszar (Eds.), Priročnik za učitelje dvojezičnih šol v Prekmurju [Manual for Teachers of Bilingual Schools in Prekmurje] (pp. 20-27). Lendava, Slovenia: Zavod za kulturo madžarske narodnosti.

Novak-Lukanovič, S. (2009). Stališča učencev do modelov izobraževanja. In L. Čok (Ed.), 
Izobraževanje za dvojezičnost v kontekstu evropskih integracijskih procesov. Učinkovitost dvojezičnih modelov izobraževanja v etnično mešanih okoljih Slovenije [Education for Bilingualism in the Context of European Integration Processes. The Effectiveness of Bilingual Education Models in the Ethnically Mixed Environments of Slovenia] (pp. 149-171). Koper, Slovenia: Založba Annales.

Novak-Lukanovič, S., \& Zver, S. (2013). Dvojezično izobraževanje: Izbrani primeri v svetu. In M. Pisnjak, M. Berden, \& J. Novak Csaszar (Eds.), Priročnik za učitelje dvojezičnih šol v Prekmurju [Manual for Teachers of Bilingual Schools in Prekmurje] (pp. 500-534). Lendava, Slovenia: Zavod za kulturo madžarske narodnosti.

Pertot, S. (2011). Bilingual Childhood: Instructions for Use. Associazione Temporanea di scopo "Jezik-Lingua".

http://www.jezik-lingua.eu/ProxyVFS.axd/null/r13414/Dvojezicno-otrostvo-Infanzia-b ilingue.pdf?ext=.pdf

Rizman, R. (1998). Multikulturalizem in izzivi globalizacije. In 34. Seminar of Slovene Language, Literature and Culture (pp. 125-135). Ljubljana: Filozofska fakulteta.

Sirna Terranova, C. (1997). Intercultural Pedagogy: Concepts, Problems, Proposals. Milano: Guerrini.

Varga, Š., Šebjanič, V., Tot Savinec, M., Hozjan, B., Milekšič, V., Kumer, I. et al. (2005). Implementation Instructions. Implementation of the 9-Year Bilingual Elementary School Program. Ljubljana: Zavod republike Slovenije za šolstvo.

Vrečer, N. (2009). Intercultural Competences in Adult Education. Ljubljana: Andragoški center Republike Slovenije.

Zavratnik Zimic, S., Apovnik, P., Komac, M., \& Makarovič, M. (1998). Conversations with Carinthian Slovenes: On Ethnic Identity, Slovene, Bilingual Education and Self-Esteem. Celovec: Mohorjeva založba.

Zoletto, D. (2007). Stranger in the Classroom. A Pedagogy of Hospitality. Milano: Raffaello Cortina Editore. 